\title{
Gene Silencing: The Mechanism to Down Regulate the Target Gene
}

\author{
Shreya ${ }^{1 *}$, Ajeet Kumar Pandey ${ }^{2}$ and H. R. Bhandari ${ }^{3}$
}

\author{
${ }^{1}$ Dept.of Genetics \& Plant Breeding, College of Horticulture, SDAU, Jagudan, Mehsana, Gujarat (384 460), India \\ ${ }^{2}$ Dept.of Genetics \& Plant Breeding, IAS, BHU, Varanasi, Uttar Pradesh (221 005), India \\ ${ }^{3}$ Central Seed Research Station for Jute \& Allied Fibres, Burdwan, West Bengal (713 403), India
}

\author{
Corresponding Author \\ Shreya \\ e-mail: shreyasinghgpb@gmail.com
}

\author{
Article History \\ Article ID: AR1895 \\ Received in $26^{\text {th }}$ October, 2018 \\ Received in revised form $05^{\text {th }}$ November, 2018 \\ Accepted in final form $12^{\text {th }}$ November, 2018
}

\begin{abstract}
Gene silencing is one of the most efficient and promising functional genomics tools which down regulates the expression of a gene in a very precise manner and has significant impact on crop improvement. Silencing of a target gene can be achieved at two levels; transcriptional and post- transcriptional stages. In broader sense, transcriptional gene silencing occurs through the repression of the process of transcription while the post transcriptional gene silencing can occur through the degradation of the mRNA. Small RNA molecules like siRNAs \& miRNAs are key players which mediate the mechanism of gene silencing. These small RNA molecules are generated through Dicer digestion of the endogenous or exogenous dsRNA by which RISC (RNA induced gene silencing complex) is activated which inhibits expression of a gene. Apart from these small RNA molecules, viruses can also accomplish gene silencing which is known as VIGS (Virus induced gene silencing). VIGS consists of cloning and inserting plant endogenous gene sequences in recombinant viral vectors, which are then inoculated in plants, triggering RNA interference. Gene silencing as reverse genetic tool, has been exploited successfully to build up the resistant against biotic (insect/pest, nematodes, viruses etc.) and abiotic stresses (drought, salinity, frost etc.), and for the enhancement of yield and quality parameters. With the development of cutting edge biotechnological tools and techniques, it is now affordable to knock down/down regulate the expression of any undesirable gene. Ultimately this kind of technology can be important to global food security and sustainability.
\end{abstract}

Keywords: Gene silencing, PTGS, TGS, miRNA, VIGS, ds RNA

\section{Introduction}

The world population has already reached 7.6 billion (2017) and is increasing day by day at an exploding rate. According to an estimate, the world population will attain the size of 9.8 billion (UN Report, 2017 and FAO Revised Report 2012) by 2050 . To feed this huge population, approximately $50 \%$ increase in the total food grains production will be required, seemingly a herculean task (FAO Revised Report, 2012, FAO 2017). Agricultural sector/business is persistently threatened by various factors of which climatic change has emerged as the most potent factor which includes an abnormal rise in temperature, irregular rain distribution, rainfall intensity, frost, drought, hail-storms etc., which directly or indirectly affect crops by retarding their growth and development resulting ultimately in reduced yield and poor quality of crop produce. Different biotic (insect pest and diseases) and abiotic stresses (like drought, salinity, frost etc.) decrease the productivity of crops (Rejab et al., 2014). There is significant loss in the yield due to the attack of pathogens in almost all the horticultural and agricultural crop species. Hitherto, these issues have been attended by traditional plant breeding approaches to confront these problems. Many efficient cultivars with inbuilt resistance/tolerance towards different threats have been developed and germplasms with novel traits identified (Das., 2015). However, these methods suffer from the limitation of being time-consuming and cumbersome process. The problem gets aggravated by the scarcity of germplasm resources available for the breeding programme for the crop improvement.

The advances in biotechnology and genetic engineering tools (like rDNA technology, genetic transformation techniques etc.) have widened the possibilities of transfer of novel trait/gene from related and even from unrelated species also into a cultivar (Ali et al., 2010; Ramon et al., 2014). Different molecular and advanced techniques like gene mapping, haploid mapping, genome sequencing have proved their potentials in identifying the different genes. In crop improvement, many a times it is required to silence/ down regulate a target gene. In order to down regulate the expression of any target gene, gene silencing mechanisms offer an explicit opportunity. The two major stages amenable to gene silencing are transcriptional and post transcriptional 
stages. The transcriptional gene silencing approaches render the target DNA sequences not suitable for transcription (Dash et al., 2015; Pathak and Gogoi, 2016). It may involve the alteration in promoter and enhancer sequences efficiencies, methylation patterns, histone modifications, addition or deletion of specific sequences etc. whereas the post transcriptional gene silencing approaches basically act upon the targeted mRNA molecule generated after the transcription. It may involve the action of ribozymes, antisense RNAs or the interfering RNA (RNAi). This review presents an overview of gene silencing process, particularly of those operating at post transcriptional stage, their mechanism and applications in crop improvement.

\section{Concept of Gene Silencing}

Gene silencing (GS) is defined as a molecular and very efficient reverse genetic tool (Dash et al., 2015) which down-regulates the activity of specific genes. Broadly speaking, gene silencing is an epigenetic process of gene regulation and is used to describe the 'switching off' of a gene by a mechanism other than the modifications in the DNA sequence. It is supposed that the mechanism of GS has evolved as a genetic defense system against viruses and invading nucleic acids (Blair and Olson, 2015). GS is highly conserved evolutionarily and involves the degradation of RNA molecules (Chen and Rajewsky, 2007). The GS phenomenon is related to RNA activity within the cell that is why it is also referred as RNA silencing. Transcription can be recalled as a process of synthesis of RNA from DNA. It means that whatever the genetic information which is carried by DNA is transferred in the form of RNA especially in the form of mRNA (messenger RNA). As soon as the different types of RNA are formed inside the nucleus, it passes through the nuclear pore and before reaching to the cytoplasm, it is processed and get stabilized so that it becomes resistant to the different endo- and exo-nuclease activities present within cytoplasm of the cell. In the case of synthesis of messenger RNA, initially pre-mRNA is formed and subsequent to splicing of introns, it becomes mature and thereafter called as the mRNA. After the formation of the mature mRNA, the genetic information which is present in the form of genetic code is decoded in the form of protein through an important molecular mechanism called as translation. The product of translation is the polypeptide chain or protein, the basic component of the enzymes or hormones which is reflected in the form of various metabolic pathways, function and phenotype of an organism. In nutshell, GS inhibits the expression of a gene thereby nullifying its harmful effect or by inhibiting the expression of a harmful or deleterious gene or sometimes an appropriate gene construct is made that contains a gene sequence to inhibit the function of a harmful gene and simultaneously introduce a beneficial gene also. Through research, it has been found that the key factor which induces the mechanism of gene silencing is the presence of double stranded RNA (dsRNA) in the cytoplasm (Fire et al., 1998). One of the most common and widely employed mechanisms of gene silencing is RNA interference (RNAi) being discussed in detail further. This RNAi approach has opened new avenues in the development of eco-friendly techniques for crop improvement as specific deleterious genes are made to be suppressed which otherwise cause stress and expression of novel genes for disease resistance (Younis et al., 2014) and for other economical and agronomical traits as well.

\subsection{Mechanism of post transcriptional gene silencing}

There are so many ways to silence a gene viz., RNA (RNA interference which includes miRNA and siRNA), PTGS (Post transcriptional gene silencing), TGS (Transcriptional gene silencing) and VIGS (Virus induced gene silencing). Gene silencing was initially reported in plants, where it was denominated as Post Transcriptional Gene Silencing (PTGS) (Napoli et al., 1990; Zhu., 2013; Morris et al., 2014). The phenomenon was subsequently described in fungus (Cogoni and Macino, 1997) and in animals, where it is known as quelling and RNA interference (RNAi), respectively (Fire et al., 1998). Post transcriptional gene silencing (PTGS) is of widespread occurrence. PTGS is the result of the destruction or blocking of a target mRNA so that it is no longer available for the next step of gene expression i.e., translation. Among various ways of PTGS, RNA interference (RNAi) is most efficient and widely applied one.

\section{Different Types of GS Mechanism}

\subsection{RNAi/PTGS/Quelling}

RNA interference (RNAi) is a general name given to a post transcriptional gene-silencing process that is induced by double-stranded RNAi.e., dsRNA (Fire et al., 1998). This Process results in down-regulation of a gene at the RNA level (i.e., after transcription), thereby causing degradation of target mRNA. RNAi is triggered by small noncoding RNA. By base pairing with the target mRNA, these small RNA does not allow the later to be expressed. It is known as 'quelling' in fungi (Romano and Macino, 1992), 'PTGS' in plants and 'RNAi' in animals. The term RNAi (RNA interference) was first coined by Fire et al., in 1998, when they discovered that injection of dsRNA into the nematode Caenorhabditis elegans resulted in potent and specific silencing of expression of the endogenous gene homologous to the injected RNA. This has been widely used as a knock-down technology to analyze gene function (Hannon, 2002, Scott et al., 2013) in various organisms. In the past few years, RNAi has become one of the most exciting discoveries in biology, for its high specificity, accuracy and transitivity (Yu et al., 2013).

\subsubsection{History of RNAi}

The path to the discovery of RNAi was first laid by R. Jorgensen (1990) while working on Petunia hybrid L, a winter annual flowering plant. They generated a transgenic petunia with the aim to intensify the purple colour of flower by constructing the sense gene construct of flavonoid/anthocyanin synthesis gene (chs $A$ and $d f r$ genes) homologous to the endogenous gene of 
Petunia (Napoli et al., 1990 ; Luo et al., 2013). In Petunia, two genes, Chalcone synthase (chs) and Dihydro flavonol reductase $(d f r)$ are involved in metabolism of petal pigmentation (Krol et al., 1990, Koch and Kogel, 2014). When these genes were introduced into petunia using a strong viral promoter (CaMV 35), dramatic change in the flower pigmentation pattern was observed, i.e. dark purple, chimeric purple and white and completely white flowers were recovered from the transgenic plants. In order to explain the latter two outcomes, i.e. chimeric and completely white flowers, it was suggested that the targeted mRNA levels dropped to different degrees and so did the pigment level in many transgenics. Chimeric or white flowers were obtained against the expected only dark purple coloured petunia flowers. This event led to the conclusion that the transgene was not apparently expressed and it ended with the silencing of the homologous native gene of petunia colour formation i.e. there was the suppression of both endogenous and exogenous gene. The phenomenon was termed as "co-suppression". Further it was investigated that this very phenomena of co-suppression was unstably transmitted within generations leading to the hypothesis that it was mediated by a nucleic acid, presumably RNA. Suppression was mostly due to the increased degradation of the mRNAs (from the endogenous and introduced genes) even though there was significant synthesis of mRNA. The outcomes and interpretations of this transgenic petunia dispersed a light to the other researchers and showed a path so that they could go into the depth of the real phenomena of gene silencing. Apparently, the real mechanism of the RNAi was actually proposed by two scientist Andrew Z. Fire and Craig C. Mello in 1998 while working on the nematode (Caenorhabditis elegans) and the term RNAi was first time coined by Fire in the same year (Fire et al., 1998; Sharma et al., 2013). Their experiment on gene silencing in nematode was a scientific breakthrough (Couzin, 2002) in the field of molecular genetics and their findings revealed that the dsRNA mediated the phenomena of RNAi or gene silencing (Mello and Conte, 2004, Dash et al., 2015). For this significant discovery, Fire and Mello were awarded with the Nobel Prize in Physiology or Medicine in the year 2006. Since then, this phenomenon has been extensively applied to suppress gene function and has become a common tool for the functional analysis of the genome (Sharma et al., 2013; Younis et al., 2014; Mermigka et al., 2015; Guo et al., 2016; Liu et al., 2017; Carbonell and Darosa 2017; Hua et al., 2018). Some applications of gene silencing have been represented in the Table 1.

Key Features of RNAi includes, silencing at post transcriptional level, double stranded nature of silencing molecule, presence of catalytic and amplification process, heritable and systemic silencing, extremely high specificity of the silencing process.

\subsubsection{Components of RNAi}

\subsubsection{The double stranded RNA (dsRNA)}

There are two main effectors of RNAi, i.e. small interfering RNA (siRNA) and micro RNA (miRNA) generated by the enzymatic processing of the longer dsRNA and stem loop precursors (Bernstein et al., 2001; Hammond et al., 2000; Stevenson, 2004). One of the most basic components of RNAi is the presence of double stranded RNA (dsRNA). This dsRNA is either produced endogenously (by transcription of mir gene in case of animals) or is induced transgenetically. In case of transgenes, the dsRNA is generated by the action of host RNA dependent RNA polymerase ( $R d R p$ ) (Dalmay et al., 2000). The transgenes that insert as or rearrange to inverted tandem repeats may also generate dsRNAs after transcription (Waterhouse et al., 1998).

\subsubsection{The dicer}

The characterization of Dicer enzyme was first presented by Bernstein et al. (2001) in Drosophila. The dicer catalyzes the production of siRNAs from the long dsRNA and requires ATP for this function. It is a large ( $220 \mathrm{kDa})$ multi-domain protein and act as an anti-parallel dimer.

\subsubsection{Drosha}

While attempting to decipher the mechanism of biogenesis of miRNA, Lee et al. (2003) reported to have identified an enzyme of RNAse III family. This was named Drosha that catalyses the nuclear processing of pri-miRNA in to premiRNA, the stem loop precursor of about 70 nucleotides which is further acted upon by dicer to generate miRNA.

\subsubsection{Argonaute protein}

Argonaute proteins constitute the catalytic unit of the RISC (RNA induced silencing complex). Argonaute proteins contain four conserved domains: The $\mathrm{N}$ - terminal, PAZ, mid and PIWI domains. The PAZ domain is responsible for small RNA binding and the PIWI domain confers the catalytic power (Hutvagner and Simard, 2008)

\subsubsection{RNA dependent RNA polymerases (RdRP)}

$\mathrm{RdRp}$ is primarily found in RNA virus where it catalyses its genome multiplication. RNA-dependent RNA polymerases (RdRPs) catalyze the formation of phosphodiester bonds between ribonucleotides in an RNA template-dependent fashion (Kenneth et al., 2008). More than 40 years ago, RdRP activity was detected in the tissue of numerous plants (Birchler et al., 2009; Hunter et al., 2016). RdRp is involved in the regeneration of dsRNA which is the key component in the gene silencing (Dalmay et al., 2000; Smith et al., 2004).

\subsubsection{Mechanism of RNAi/PTGS}

The involvement of small RNAs (21-26 nucleotides) is the peculiar characteristics of this phenomena that act as specific determinants for down-regulating gene expression (Waterhouse et al., 2001; Hannon, 2002; Pickford and Cogoni, 2003). For this process, proteins belonging to the Argonaut family are also required (Hammond et al., 2000). But the actual process of RNAi is triggered by the action of long dsRNA intermediates which is further digested by Dicer enzyme (a ribonuclease III enzyme) into the small dsRNA of 21-24 nucleotides long with characteristics 3'- dinucleotide 


\begin{tabular}{|c|c|c|c|}
\hline Crop & Genes/Enzymes/pathogens & Results & References \\
\hline Zea mays & $\begin{array}{l}\text { Knocking out } 22-\mathrm{kD} \text { maize zein storage } \\
\text { protein expression }\end{array}$ & High levels of lysine-rich proteins & -------------------- \\
\hline Wheat & $\begin{array}{l}\text { Down regulating starch- branching } \\
\text { enzyme (SBE) II (SBE II a and SBE II B) in } \\
\text { wheat endosperm }\end{array}$ & High amylose content in wheat & Tang et al., 2007 \\
\hline Barley & $\begin{array}{l}\text { Resistant to BYDV (Barley yellow dwarf } \\
\text { virus) }\end{array}$ & Resistance against yellow dwarf virus & Wang et al., 2000 \\
\hline Rice & Reduced the level of glutein & $\begin{array}{l}\text { Produced variety LGC-1, was a relief } \\
\text { of the kidney patients unable to digest } \\
\text { glutein }\end{array}$ & Kusabaet al., 2003 \\
\hline Banana & $\begin{array}{l}\text { BBrMV (Banana Bract Mosaic Virus), } \\
\text { silencing of coat protein gene }\end{array}$ & Banana cultivar resistant to BBrMV & Rodoniet al., 1999 \\
\hline Cotton & d-cadinene synthase gene & $\begin{array}{l}\text { Reduced gossypol, an anti-nutritional } \\
\text { factor of cotton seed and increased } \\
\text { nutritional value of seed }\end{array}$ & Kumar et al., 2006 \\
\hline Jute & Enzyme 4- coumarate: Co.Alogage (4C1) & Reduced the lignin production in jute & ----------- \\
\hline Latyrussativus & $\begin{array}{l}\text { neurotoxin called oxalylaminoalanine-L- } \\
\text { alanine (BOAA) }\end{array}$ & Low BOAA content lathyrus. & Spencer et al., 1986 \\
\hline Tomato & DE-ETHIOLATED1 gene (DET1) & $\begin{array}{l}\text { Improve carotenoid and flavonoid } \\
\text { levels in tomato fruits with minimal } \\
\text { effects on plant growth and fruit qual- } \\
\text { ity parameters }\end{array}$ & Davuluriet al., 2005 \\
\hline Coffee & Caffeine producing gene & Low or very low caffeine content & Van Uyen, 2006 \\
\hline $\begin{array}{l}\text { Carnation, petu- } \\
\text { nia, torenia and } \\
\text { tobacco }\end{array}$ & Chalcone synthase (CHS) gene & $\begin{array}{l}\text { Blue colour carnation flower, Altered } \\
\text { flowercolour. }\end{array}$ & $\begin{array}{l}\text { Tanaka et al., 2005, } \\
\text { Nishihara et al., 2006, } \\
\text { Nakatsuka et al., 2008 }\end{array}$ \\
\hline Blue rose & $\begin{array}{l}\text { Knock down the cyanidin genes in rose } \\
\text { and carnation and also they introduced } \\
\text { delphinidin genes }\end{array}$ & $\begin{array}{l}\text { To produce blue coloured flower } \\
\text { which is not its natural colour }\end{array}$ & ------------- \\
\hline $\begin{array}{l}\text { Arabidopsis flow- } \\
\text { ering time }\end{array}$ & A gene called FLC w & To bring flowering & $\begin{array}{l}\text { Waterhouse et al., } \\
1998\end{array}$ \\
\hline Soybean oil quality & $\begin{array}{l}\text { Omega-3 fatty acid desaturase } \\
\text { (GmFAD3A, GmFAD3B and GmFAD3C) }\end{array}$ & $\begin{array}{l}\text { Transgenic soybean seed with low } \\
\text { level ( } 1-3 \%) \text { of alpha-linoleic acid. }\end{array}$ & Flores et al., 2008 \\
\hline Potato & Phytophthorainfestans & Resistance against late blight & -------------- \\
\hline Papaya & Papaya ring spot virus & Resistant variety & Ding, 2010 \\
\hline Cucumber & Green motle mosaic virus & Resistant variety & Ding, 2010 \\
\hline Rice & Rice stripe virus & Resistant variety & Ding, 2010 \\
\hline
\end{tabular}

overhang, a 5' monophosphate and a 3'- hydroxyl group. RNAi operates by triggering the action of dsRNA intermediates, which are processed into RNA duplexes of 21-24 nucleotides by a ribonuclease III-like enzyme called Dicer (Fire et al., 1998; Bernstein et al., 2001). The processed product by Dicer i.e., small dsRNA is the solely responsible for gene silencing and hence, these small dsRNA are also referred as small interfering RNAs and represented as siRNA. As soon as the small interfering dsRNA is formed, the two strand of this dsRNA gets separated. One of the separated strands i.e., guide or antisense strand from the siRNA which is complementary to the target sequence is directed towards the assembly of RISC (RNA induced silencing complex) and the second which is not involved in RISC, gets digested (Hammond, 2000; Tang 
2003). The RISC is composed up of guide RNA (one strand of siRNA) and certain proteins from the Argonaute family. The guide RNA scans the host genome to target the degradation of complementary messenger RNAs (mRNAs) and once RISC reaches at the target site, the endonuclease activity of the protein of Argonaute family chops that sequence and thus renders the target gene unexpressed. The schematic representation of the RNAi mechanism is presented in the Figure 1.

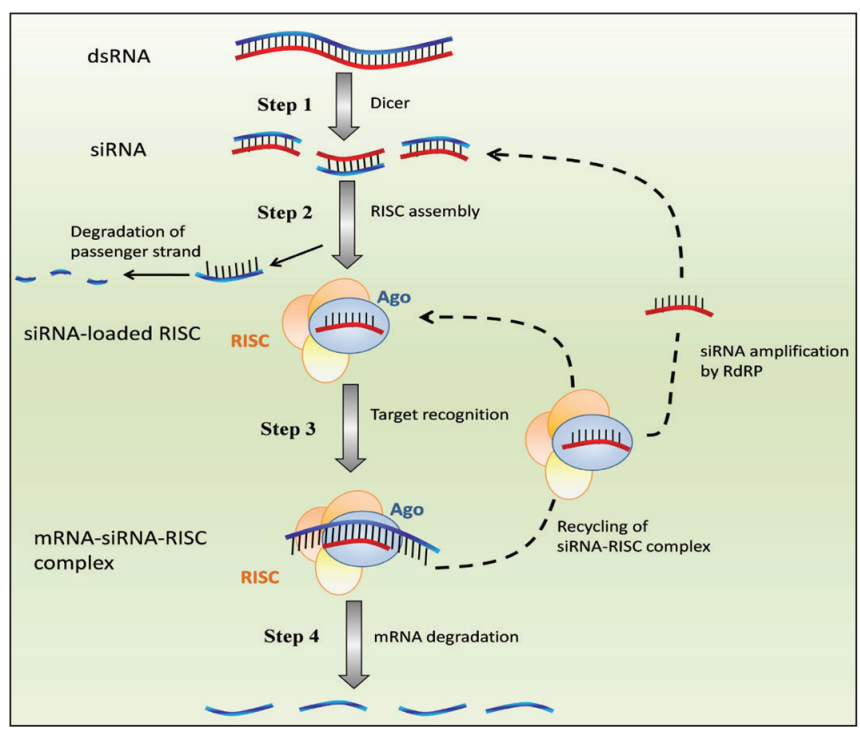

Figure 1: Schematic representation of RNAi (Figure source: Cuccato et al., 2011)

There are several sources triggering the synthesis of dsRNA which may be formed from the endogenous genes, transgenic antisense sequences through expression of inverted repeat sequence or through RNA synthesis during viral replication (Voinnet, 2005). Triggering of systemic gene silencing of other genes in the organism is one of the most electrifying features of this reverse genetic molecular mechanism. As soon as silencing of a gene is achieved in a particular cell, signals will be received by the adjoining cells due to the cleavage of dsDNA into siRNAs (act as mobile signal) which eventually results into the silencing of entire system's target 's gene (Voinnet et al., 1998; Hannon, 2002). Moreover, the enzymatic activity of RISC also boosts the silencing reaction by mediating multiple turnover reactions (Tang et al., 2003).

\subsection{TGS/Transcriptional gene silencing}

It is the mechanism of gene silencing which is accomplished before the transcription of mRNA and is facilitated through chromatin remodeling and DNA methylation (Waterhouse et al., 2001). The small RNAs produced by DCL cleavage can induce silencing both at the post-transcriptional level as well as at the transcriptional level. The mechanism of TGS is mediated by small RNA ( 24 ntds) produced by DCL3 cleavage of dsRNA which often uses RDRP (RNA dependent RNA polymerase). Chromosomal modifications such as DNA methylation at cytosine residues and histone methylation at specific lysine residues also induces the gene silencing through TGS because excessive methylation causes heterochromatization (Ye and Singer, 1996; Wassenegger and Pelissier, 1998; Wassenegger, 2002; Alberts et al., 2002). Sometimes, methylation of promoters causes chromosome remodeling thereby inhibiting the transcriptional factors to be attached at the promoters (Kooter et al., 1999). It has been reported that the magnitude of DNA methylation is found to be more in the matured meristematic cells as compared to the younger diving cells thus, clearing that DNA methylation is involved in aging process in Pinus radiata (Fraga et al., 2002).

The deeply stained region of DNA are supposedly genetically inactive and very much condensed which is due to the ubiquitination, phosphorylation, methylation and acetylation of core histone proteins $(\mathrm{H} 2 \mathrm{~A}, \mathrm{H} 2 \mathrm{~B}, \mathrm{H} 3$ and $\mathrm{H} 4)$ which are deeply involved in gene regulation (Lippman and Martienssen 2004, Griffiths et al., 1998). When there is chemical changes in the tails of histones proteins, it generates a signal which regulates the accessibility of cells transcriptional machinery to the DNA through chromatin remodeling (Alberts et al., 2002).

According to certain researches carried out in Arabidopsis indicates and Schizosaccharomyces pombe, these iRNA generate the signal for DNA methylation which is transmitted from cytoplasm to the nucleus (Xie et al., 2004). On the other hand, RNAi effector complex termed RNA induced Initiation of Transcriptional gene Silencing (RITS) required for heterochromatin assembly in fission yeast (Schizosaccharomyces pombe) (Verdel et al., 2004).

\section{3. microRNA (miRNAs) mediated gene silencing}

micro RNA was first reported in Caenorhabditis elegans by the discovery that the lin- 4 gene coded a pair of small RNAs instead of a protein (Lee et al., 1993). The microRNA (mi RNA) is the first and recently discovered small regulatory RNA in plants and animals. Micro RNAs are small dsRNA like siRNA which can also silence a gene by promoting their degradation or repressing their translation (Bartel, 2004; Duan et al., 2006). All the mRNA which leave the nucleus may or may not be translated many times to make proteins. The miRNA is first transcribed as a long RNA molecule, which forms base pairs with itself and folds over to make a hairpin. The hair pin is chopped up by enzymes, releasing a small double stranded fragment of about 22 nucleotides. One of the strands in this fragment is the mature microRNA (miRNA), which binds to a specific protein to make an RNA-Protein complex (Reinhart et al., 2002). The microRNA directs the protein complex to matching mRNA molecules (ones that form base pairs with the miRNA). If the miRNA and its target match perfectly, an enzyme in the RNA-Protein complex will typically chop the mRNA in pieces, leading to its breakdown (Rhoades et al., 2002). If the miRNA and its target have some mismatches, the RNA-protein complex may instead remain bound to the mRNA and keep it from being translated (Chen, 2007). DCL 1 (Dicer) generally processes the miRNA in nucleus (Papp et al., 2003). 


\subsection{VIGS (Virus Induced gene silencing)}

Van Kammen first used the term virus induced gene silencing (VIGS) and described VIGS as a phenomenon to recover from virus (1997). Moreover in reality the technique of VIGS include the recombinant viruses to knock down endogenous gene expression (Ruiz et al., 1998, Wu et al., 2010; Chen et al., 2013). Various types of viruses like DNA and RNA vectors can be used to silence a gene in plants (Timmermans et al., 1994, Schwessinger and Ronald, 2012; Yang and Zang, 2017). Out of two types of vectors, DNA viruses face difficulty in mobilization on account of larger genome size. As a result, DNA viruses are not preferred over the RNA viruses vectors. These RNA vectors carry a 23 nucleotide long sequence which is homologous to the target sequence which is to be silenced. The VIGS can be seen as a rapid way to silence the gene. The first RNA virus based gene silencing vector was based on TMV used in Nicotiana benthamiana to silence the sequence of Phytotene Desaturase (PDS). Now a days various virus based vectors has been developed to build resistance in plants against viruses which is represented in the Table 2.

\begin{tabular}{|c|c|c|c|c|c|}
\hline Vector & Viral symptoms & Species $^{1}$ & Efficiency ${ }^{2}$ & $\begin{array}{l}\text { Adopted for large- } \\
\text { scale studies }\end{array}$ & Reference \\
\hline TMV & N. benthamiana & Severe & $\begin{array}{l}\text { Fair; better with antisense Improved } \\
\text { with inclusion of direct inverted repeats }\end{array}$ & Yes & Lacommeet al., 2003 \\
\hline PVX & N. benthamiana & Moderate & Fair; not persistent & Yes & Ruiz et al., 1998 \\
\hline TGMV & N. benthamiana & Variable & $\begin{array}{l}\text { Fair; varies with gene silenced, size of } \\
\text { insert }\end{array}$ & No & Kjemtrupet al., 1998 \\
\hline TRV & Tomato & Mild & $\begin{array}{l}\text { Variable; depends on inoculation tech- } \\
\text { nique }\end{array}$ & $\begin{array}{l}\text { Yes, available for } \\
\text { GATEWAY cloning }\end{array}$ & Liu et al., 2002 \\
\hline BSMV & Barley & Moderate & $\begin{array}{l}\text { Fair; depends on target sequence; not } \\
\text { persistent Improved with use of direct } \\
\text { inverted repeats of targeting sequence }\end{array}$ & Yes & Lacommeet al., 2003 \\
\hline
\end{tabular}

TMV: Tobacco mosaic virus; PVX: Potato virus X; TGMV: Tomato golden mosaic virus; TRV: Tobacco rattle virus; BSMV: Barley stripe mosaic virus; 1: Plant species in which silencing has been shown to be effective; 2: Efficiency is the percentage of leaf area that shows evidence of silencing and the degree of silencing that occurs

\section{Conclusion}

Considering the successful results from different applications of the various mechanism of the gene silencing in wide range of agricultural and horticultural crop plants, it has been proved that the techniques of gene silencing are very effective in solving of production constraints like increasing the quality of produce, building resistance against different pathogens and pests and creating the new useful variation by suppressing the endogenous genes as well. Hence, this technology can be seen as to lower the production gap.

\section{References}

Alberts, B., Johnson, A., Lewis J., Raff, M., Roberts, K., Walter, P., 2002. Molecular biology of the cell (14 ${ }^{\text {th }}$ Edn). Garland Science, New York, 463

Alexandratos, N., Bruinsma, J., 2012. World agriculture towards 2030/2050: the 2012 revision. Global Perspective Studies Team FAO Agricultural Development Economics Division

Ali, N., Datta, S.K., Datta, Karabi., 2010. RNA interference in designing transgenic crops. GM Crops 1 (4), 207-213.

Bartel, D.P., 2004. microRNAs : Genomics, biogenesis, mechanism and function. Cell (116), 281-297.

Bernstein, E., Caudy, A.A., Hammond, S.M., Hannon, G.J.,
2001. Role for a bidentate ribonuclease in the initiation step RNA interference. Nature (409), 363-366.

Blair, C.D., Olson, K.E., 2015. The Role of RNA Interference (RNAi) in Arbovirus-Vector Interactions. Viruses (7), 820-843.

Birchler, J.A., 2009. Ubiquitous RNA-dependent RNA polymerase and gene silencing. Genome biology 10, 243.

Carbonell, A., Daros, J.A., 2017. Artificial microRNAs and synthetic transacting small interfering RNAs interfere with viroid infection. Molecular Plant Pathology 18, 746-753.

Chen, K., Rajewsky, N., 2007. The evolution of gene regulation by transcription factors and microRNAs. Nature Review Genetics 8, 93-103.

Chen, T.Z., Lv, Y.D., Zhao, T.M., 2013. Comparative transcriptome profiling of a resistant vs. susceptible tomato (Solanum lycopersicum) cultivar in response to infection by tomato yellow leaf curl virus, Public Library of Science One 8(11), e80816.

Cogoni, C., Macino, G., 1997. Isolation of quelling-defective (qde) mutants impaired in posttranscriptional transgeneinduced gene silencing in Neurospora crassa. Proceedings of National Academy of Science, USA 94, 10233.

Couzin, J., 2002. Small RNAs make big splash. Science 298, 
2296-2297.

Cuccato, G., Polynikis, A., Siciliano, V., Graziano, M.M., di Bernardo, M., di Bernardo, B., 2011. Modeling RNA interference in mammalian cells. BMC Systems Biology 5, 19.

Dalmay, T., Hamilton, A., Rudd, S., Angell, S., Baulcombe, D.C., 2000. An RNA-dependent RNA polymerase gene in Arabidopsis is required for posttranscriptional gene silencing mediated by a transgene but not by a virus. Cell 101, 543-553.

Das, S., 2015. RNA Interference: An Environment Friendly Approach for Targeted Pest Management 4(3), 1000e112

Dash, S.K., Mohapatra, S.K., Malik, H.N., 2015. RNA Interference-A fine tuner of gene regulation: a Review. International Journal of Biotechnology and Molecular Biology Research 6, 35-39.

Davuluri, G.R., vaTuinen, A., Fraser, P.D., Manfredonia, A., Newman, R., Burgess, D., Brummell, D.A., King, $S, R$, Palys, J., Uhlig, J., Bramley, P.M., Pennings, H.M., Bowler, C., 2005. Fruit specific RNAi- mediated suppression of DET1 enhances carotenoid and flavonoid content in tomatoes. Nature Biotechnology 23, 890-895.

Ding, S.W., 2010. RNA-based antiviral immunity. Nature Review of Immunology 10, 632-644.

Duan, C.G., Wang, C.H., Guo, H.S., 2006. Regulation of microRNA on plant development and viral infection. Chinese Science Bulletin 51, 269-278.

Fire, A., Xu, S., Montgomery, M.K., Kostas, S.A., Driver, S.E., Mello, C.C., 1998. Potent and specific genetic interference by double-stranded RNA in C. elegans. Nature 391, 806-811.

Flores, T., Karpova, O., Su, X., Zeng, P., Bilyeu, K., Sleper, D.A., Nguyen, H.T., Zhang, Z.J., 2008. Silencing of GmFAD3 gene by siRNA leads to low alpha-linolenic acids (18:3) of fad3-mutant phenotype in soybean [Glycinema $x$ (Merr.)]. Transgenic Research 17, 839-850.

Fraga, M.F., Rodriguez, R., Canal, M.J. 2002.Genomic DNA methylation-demethylation during aging and reinvigoration of Pinus radiata. Tree Physiology 22, 813-816

Hua, C., Zhao, J.H., Guo, H.S., 2018. Trans-Kingdom RNA Silencing in Plant Fungal Pathogen Interactions. Molecular Plant 11, 235-244

Hunter, L.J.R., Brockington, S.F., Murphy, A.M., Pate, A.E., Gurden, K., MacFarlane, S.A., Palukaitis P., Carr, J.P., 2016. RNA-dependent RNA polymerase1 in potato (Solanum tuberosum) and its relationship to other plant RNA-dependent RNA polymerases. Scientific Reports 6, 23082.

Hutyagner, G., Simard, M.J., 2008. Argounaute proteins: Key players in RNA silencing. Nature Reviews Molecular Cell Biology 9 (1), 22-32.

Griffiths, A.J.F., Miller, J.H., Suzuki, D.T., Lewontin, R.C., Gelbart, W.M., 1998. Introducao a genetica (6 $6^{\text {th }}$ Edn.).
Rio de Janeiro, Guanabara Koogan, 856

Guo, Q., Liu, Q., Smith, A.N., Liang, G., Wang, M.B., 2016. RNA Silencing in Plants: Mechanisms, Technologies and Applications in Horticultural Crops. Current Genomics 17, 476-489.

Hammond, S.M., Bernstein, E., Beach, D., Hannon, G.J., 2000. An RNA-Directed Nuclease Mediates PostTranscriptional Gene Silencing in Drosophila Cells. Nature 404, 293-296.

Hannon, G.J., 2002. RNA interference. Nature 418, 244-251.

FAO, 2017. The future of food and agriculture: Trends and challenges. Rome, FAO of UN. Available from: http:// www.fao.org/3/a-i6583e.pdf.

Kenneth, K.S.Ng., Arnold, J.J., Cameron, C.E., 2008. StructureFunction Relationships among RNA-Dependent RNA Polymerases. Current Topics in Microbiology and Immunology 320, 137-156.

Kjemtrup, S., Sampson, K.S., Peele, C.G., Nguyen, L.V., Conkling, M.A., 1998. Gene silencing from plant DNA carried by a Gemini virus. Plant Journal 14, 91-100.

Koch, A., Kogel, K.H., 2014. New wind in the sails: improving the agronomic value of crop plants through RNAimediated gene silencing. Plant Biotechnology Journal 12, 821-831.

Kooter, J.M., Matzke, M.A., Meyer, P., 1999. Listening to the silent genes: Transgene silencing, gene regulation and pathogen control. Trends in Plant Science 4, 340-347.

Kumar, G., Campbell, L.M., Puckhaber, L., Stipanovic, R.D., Rathore, K.S., 2006. Engineering cotton seed for use in human nutrition by tissue-specific reduction of toxic gossypol. Proceedings of the National Academy of Sciences of the USA 103,18054-18059.

VanderKrol, A.R., Mur, L.A., Beld, M., Mol, J.N.M., Stuitje, A.R., 1990. Flavonoid genes in Petunia: Addition of a limited number of gene copies may lead to a suppression of gene expression. Plant Cell 2, 291-299.

Kusaba, M., Miyahara, K., Lida, S., Fukuoka, H., Takario, T., Sassa, H., Nishimura, M., Nishio, T., 2003. Low glutenin content: A dominant mutation that suppresses the glutenin multigene family via RNA silencing in rice. Plant Cell 15, 1455-1467.

Lacomme, C., Hrubikova, K., Hein, I., 2003. Enhancement of virus-induced gene silencing through viral-based production of inverted-repeats. Plant Journal 34, 543-553

Lee, R.C., Feinbaum, R.L., Ambros, V.,1993. The C. elegans heteochronic gene lin-4 encodes small RNAs with antisense complementarity to lin-14. Cell 75, 843-854.

Lee, Y., Ahn, C., Han, J., Choi, H., Kim, J., Yim, J., Lee, J., Provost, P., Radmark, O., Kim, S., Kim, V.N., 2003.The nuclear RNase III Drosha initiates microRNA processing. Nature 425(6956), 415-419.

Lippman, Z., Martienssen, R., 2004. The role of RNA interference in heterochromatic silencing. Nature 431, 
364-370.

Liu, Y., Schiff, M., Dinesh-Kumar, S.P., 2002.Virus-induced gene silencing in tomato. Plant Journal 31, 777-786.

Liu, S.R., Jing-Jing, Zhou, J.J., Hu, C.G, Wei, C.L., Zhang, J.Z., 2017. MicroRNA-Mediated Gene Silencing in Plant Defense and Viral Counter-Defense. Frontiers in microbiology 8, 1801.

Luo, Y., Wang, X., Wang, X., Yu, D., Chen, B., Kang, L., 2013. Differential responses of migratory locusts to systemic RNA interference via double-stranded RNA injection and feeding. Insect Molecular Biology 22, 574-583.

Mermigka, G., Verret, F., Kalantidis, K., 2015. RNA silencing movement in plants. Journal of Integrative Plant Biology 58(4), 328-342.

Mello, C.C., Conte, D.J., 2004. Revealing the world of RNA interference. Nature 16, 338-342.

Morris, K.V., Mattick, J.S., 2014. The rise of regulatory RNA. Nature Reviews Genetics 15, 423-437

Nakatsuka, T., Mishibaa, K.I., Abe, Y., Kubota, A., Kakizaki, Y., Yamamura, S., Nishihara, M., 2008. Plant Biotechnology, Flower color modification of gentian plants by RNAi mediated gene silencing. Plant Biotechnology 25, 61-68.

Napoli, C., Lemieux, C., Jorgensen, R.,1990. Introduction of a chimeric chalcone synthase gene into petunia results in reversible co-suppression of homologous genes in trans. Plant Cell 2, 279-89.

Nishihara, M., Nakatsuka, T., Hosokawa, K., Yokoi, T., Abe, Y., Mishiba, K., Yamamura, S., 2006. Dominant inheritance of white-flowered and herbicide-resistant traits in transgenic gentian plants. Plant Biotechology 23, 25-31.

Papp, I., Mette, M.F., Aufsatz, W., Daxinger, L., Schauer, S.E., Ray, A., VanderWinden, J., Matzke, M., Matzke, A.J.M., 2003. Evidence for nuclear processing of plant micro RNA and short interfering RNA precursors. Plant Physiology $132,1382-1390$.

Pathak, K., Gogoi, B., 2016. RNA interference (RNAi): Application in crop improvement: A review Agricultural Reviews 37(3), 245-249

Press Release: The 2006 Nobel Prize in Physiology or Medicine. Nobelprize.org. Nobel Media AB 2014. http://www.nobelprize.org/nobel_prizes/medicine/ laureates/2006/press.html. Surfed on $12^{\text {th }}$ Aug, 2018.

Pickford, A.S., Cogoni, C., 2003. RNA-Mediated Gene Silencing. Cellular and Molecular Life Science 60, 871-882.

Ramon, M., Devos, Y., Lanzoni, Y,L., Gomes, A., Gennaro, A., Waigmann, E., 2014. RNAi-based GM plants: food for thought for risk assessors. Plant Biotechnology Journal 12, 1271-1273

Rejeb, I.B., Pastor, V., Mauch-Mani, B., 2014. Plant response to simultaneous biotic and abiotic stress: Molecular mechanisms. Plants 3(4), 458-475.

Reinhart, B.J., Weinstein, E.G., Rhoades, M.W., Bartel, B., Bartel, D.P., 2002. microRNAs in Plants. Genes \& Development 16, 1616-1626.
Ruiz, M.T., Voinnet, O., Baulcombe, D.C., 1998. Initiation and maintenance of virus-induced gene silencing. Plant Cell 10, 937-946.

Rodoni, B.C., Dale, J.L., 1999. Harding RM Characterization and expression of the coat protein-coding region of the banana bract mosaic poty virus, development of diagnostic assays and detection of the virus in banana plants from five countries in Southeast Asia. Archives of Virology 144, 1725-1737.

Rhoades, M.W., Reinhart, B.J., Lim, L.P., Burge, C.B., Bartel, B., Bartel, D.P.,2002. Prediction of plant microRNA targets. Cell 110, 513-520.

Romano, N., Macino, G., 1992. Quelling: Transient inactivation of gene expression in Neurospora crassa by transformation with homologous sequences. Molecular Microbiology 6, 3343-3353.

Schwessinger, B., Ronald, P.C., 2012. Plant innate immunity: perception of conserved microbial signatures, Annual Review of Plant Biology 63, 451-482.

Scott, J.G., Michel, K., Bartholomay, L.C., B.D. Siegfried, B.D., W.B. Hunter, W.B., Smagghe, G., 2013. Towards the elements of successful insect RNAi. Journal of Insect Physiology 59, 1212-1221.

Sharma, V.K., Sanghera, G.S., Kashyap, P.L., Sharma, B.B., Chandel, C., 2013. RNA interference: A novel tool for plant disease management. African Journal of Biotechnology 12(18), 2303-2312.

Smith, T.M.B., Anderson, J.C., Martin, G.B., Kumar, S.P.D., 2004. Applications and advantages of virus-induced gene silencing for gene function studies in plants. The Plant Journal 39, 734-746.

Spencer, P.S., Roy, D.N., Ludolph, A., Hugon, J., Dwivedi, M.P., Schaumburg, H.H., 1986. Lathyrism: evidence for role of the neuroexcitatory aminoacid BOAA. Lancet 2, 1066-1067.

Stevenson, M., 2004. Therapeutic potential of RNA interference. The New England journal of medicine 351, 1772-1777.

Tang, G., Galili, G., Zhuang, X., 2007. RNAi and microRNA: Breakthrough technologies for the improvement of plant nutritional value and metabolic engineering Metabolomics 3, 357-369.

Tang, G., Reinhart, B.J., Bartel, D., Zamore, P.D., 2003. A Biochemical Framework for RNA Silencing in Plants. Genes and Development 17, 49-63.

Tanaka, Y., Katsumoto, Y., Brugliera, F., Mason, J., 2005. Genetic engineering in floriculture. Plant Cell Tissue and Organ Culture 80, 1-24.

Timmermans, M., Das, O.P., Messing, J., 1994. Gemini virus and their uses as extra chromosomal replicons. Annual Review of Plant Physiology 45, 79-112.

Wang, M., Abbott, D., Waterhouse, P.M., 2000. A single copy of a virus derived transgene encoding hairpin RNA gives immunity to barley yellow dwarf virus. Molecular Plant 
Pathology 1, 401-410.

Wassenegger, M., Pelissier, T., 1998. A model for RNAmediated gene silencing in higher plants. Plant Molecular Biology 37, 349-362.

Wassenegger, M., 2002. Gene Silencing. International Review of Cytology 219, 61-113.

Waterhouse, P.M., Wang, M.B., Lough, T., 2001. Gene silencing as an adaptive defense against viruses. Nature 411, 834-842.

Waterhouse, P.M., Graham, M.W., Wang, M.B., 1998. Virus resistance and gene silencing can be induced by simultaneous expression of sense and antisense RNA. Proceedings of National Academy of Science, USA 95, 13959-13964.

Wu S.Y., Lopez-Berestein, G., Calin, G.A., Sood, A.K., 2014. RNAi therapies: drugging the undruggable, Science Translational Medicine 6, 240-255.

UN Department of Economic and social Affairs. 2017. World Population Prospects: The 2017 Revision.

Van, U., 2006. Novel approaches in plants breeding RNAi technology. Proceedings of International Workshop on Biotechnology in Agriculture 12-16.

Van, K.A., 1997.Virus-induced gene silencing in infected and transgenic plants. Trends in Plant Sciences 2, 409-411

Verdel, A., Jia, S., Gerber, S., Sugiyama, T., Gygi, S., Grewal, S.I.S., Moazed, D., 2004. RNAi-mediated targeting of heterochromatin by the RITS Complex. Science 303(5658), 672-676.

Voinnet, O., 2005. Induction and suppression of RNA silencing: insights from viral infections. Nature Review Genetics
6(3), 206-220.

Voinnet, O., Vain, P., Angell, S., Baulcombe, D.C., 1998. Systemic spread of sequence-specific transgene RNA degradation in plants is initiated by localized introduction of ectopic promoter less DNA. Cell 95, 177-187.

Yang, H., Zhang, T., 2017. Transcriptome analysis of the SmMediated hypersensitive response to Stemphylium lycopersici in tomato. Frontiers in Plant Science 8, 1257.

Ye,F., Signer, E.R., 1996. RIGS (repeat-induced gene silencing) in Arabidopsis is transcriptional and alters chromatin configuration. Proceedings of National Academy of Science of the USA 93, 10881-10886.

Younis, A., Siddique, M.I., Kim, C.K., Lim, K.B., 2014. RNA Interference (RNAi) Induced Gene Silencing: A Promising Approach of Hi-Tech Plant Breeding. International Journal of Biological Sciences 10, 50-58.

Yu, N., Christiaens, O., Liu, J.S., J.Z. Niu, J.S., K. Cappelle, K., Caccia, S., 2013. Delivery of dsRNA for RNAi in insects: an overview and future directions. Insect Science 20, 4-14.

Xie, Z., Johansen, L.K., Gustafson, A.M., Kasschau, K.D., Lellis, A.D., Zilberman, D., Jacobsen, S.E., Carrington, J.C., 2004. Genetic and functional diversification of small RNA pathways in plants. Public Library of Science Biology 2, 642-652.

Zhu, K.Y., 2013. RNA interference: a powerful tool in entomological research and a novel approach for insect pest management PREFACE. Insect Science 20, 1-3. 